\title{
Post-Truth as a Feature of Hypermodern Times
}

\author{
Miguel Ángel Quintana-Paz \\ (European University Miguel de Cervantes, Valladolid, \\ Department of Humanities)
}

\section{Introduction $^{1}$}

One of the best-known characteristics of hypermodernity is speed. It is true that authors like Paul Virilio ${ }^{2}$ had already underscored the importance of speed in order to understand our times as early as in the 1970s. But at those times (still postmodern times?) speed was mainly connected to the use of analogic technologies, like television or airplanes, as Alan N. Shapiro ${ }^{3}$ has pointed out; whereas in hypermodern times speed is connected mostly to the use of digital technologies, like computers and the Internet.

This hypermodern alliance of speed and digital technologies explains, among others, the incredibly short time that it takes for some new words to become widely known and used on a global scale. This is what has happened to the term "post-truth", which was elevated to the rank of "Word of the year" by Oxford Dictionaries in 2016. There was no record of this term before 1980, according to

This paper is based in the contribution "Post-Truth as a Feature of Hypermodern Times", that I presented at the conference Around Hypermodernism, held at the Faculty "Artes Liberales" of the University of Warsaw on June 14,2018. Paragraphs 2, 3 and 4 expand a shorter version of them that I already published in section 3.6. of my book Sapere aude, o ¿cabe llamarnos aún ilustrados?, Valladolid 2018.

2 P. Virilio, Vitesse et Politique: essai de dromologie, Paris 1977.

3 A.N. Shapiro, What is hyper-modernism?, keynote lecture at the same-named conference held at the National Center of Scientific Research (CNRS) in Paris, March 20 $0^{\text {th }}, 2016$, http://www.alanshapiro.com/what-is-hyper-modernism-by-alan-n-shapiro. 
Google Books Ngram Viewer. We had to wait till 1992, though, to see the first use of this expression with approximately the same meaning that we ascribe to it today. ${ }^{4}$ Twelve years after that, Ralph Keyes published his book The Post-truth Era, ${ }^{5}$ which definitely contributed to the popularization of the word. Nevertheless, the increase of its use followed a slow pace till the first months of 2016. It was from June 2016 onwards that it experienced a sudden boost, as the so-called Brexit referendum was taking place and the United States presidential election campaign was reaching its peak. ${ }^{6}$ This rapid surge can only be understood in a world connected through the internet: many languages experienced it at the same time. ${ }^{7}$

Now, just as the internet contributes to making fashionable words like this quite fast, it also seems to require us to understand them quickly. This is the reason why no small number of those who read the word "post-truth" have felt the compulsion, I am afraid, of immediately giving it a meaning. And I guess that they have reasoned (more or less) like this: if post-truth is clearly not the same as truth, and the opposite of "truth" is "lie", let us swiftly conclude that "post-truth" is nothing but a new label for the lies of yore (which, for some obscure reasons, have now this new trendy name).

This way of reasoning is, nevertheless, wrong. The term "post-truth" has an inescapable philosophical component (in fact, as we will try to argue here, its current success is of little surprise to those who have paid close attention to the developments of philosophy for the last forty years or so). And philosophy requires slow reflection, not the desire to understand as soon as possible any new fad. Post-truth is not the same as lying. Quite diverse philosophers like Mario Perniola, Gianni Vattimo and Harry Frankfurt have been warning us that this was going to happen, that we were entering into a post-truth world. These three

\footnotetext{
S. Tesich, A Government of Lies, “The Nation”, 1992, January 6/13, pp. 12-14.

R. Keyes, The Post-Truth Era. Dishonesty and Deception in Contemporary Life, New York 2004.

6 Data taken from Oxford Dictionaries, Word of the year 2016 is..., https://en.oxforddictionaries. com/word-of-the-year/word-of-the-year-2016.

7 In Spanish, the word "posverdad" was accepted by the Dictionary of the Royal Academy in December 2017, but it had already been used since 2003 (L. Verdú, El prisionero de las 21.30, Barcelona 2003). In French, "post-verité" was introduced at Le Petit Larousse and Le Robert illustré in June 2017. In German, "postfaktisch" was elected as word of the year in December 2016 by the Gesellschaft für deutsche Sprache (GfdS). In Italian, the Accademia della Crusca had been studying the term "post-verità" since the end of 2016 (M. Biffi: "Viviamo nell'epoca della post-verità?", Accademia della Crusca, 25 November 2016, http://www.accademiadellacrusca.it/ it/lingua-italiana/consulenza-linguistica/domande-risposte/viviamo-nellepoca-post-verit).
} 
philosophers have used different languages, they belong to different philosophical traditions, they have different feelings about the coming of the age of posttruth, each of them pays special attention to one or another of its causes and of its consequences. But none of them has trivialized our subject matter to the point of stating that all that was going on is that people were going to tell lies to a greater extent than ever before.

What does, then, "post-truth" mean, if it is not just "lying"? Let us follow the steps of the three above-mentioned philosophers: they will help us to get clear about this. But we can advance something: post-truth is not a new word for falsity, but a word that describes the times (our times) in which the difference between truth and falsity is not relevant any more. The history of philosophy is full of thinkers (Antique and Modern) who have strained to show us the way to truth and how to get rid of falsehoods; the new phenomenon that post-truth represents is that this whole epistemic endeavor is not solicited any longer.

\section{Harry Frankfurt: post-truth as bullshit}

In 1986 an American philosopher teaching at Yale, Harry Frankfurt, published a paper about the notion of "bullshit". ${ }^{8}$ It did not achieve world-wide success till nineteen years later, though, when it was re-published as a small book under the same explicit title: On Bullshit. ${ }^{9}$ The text is interesting for us here because our contention is that what Frankfurt calls "bullshit" is similar to what we have called "post-truth". And this maybe explains why a work published in the 1980s had to wait till 2005 to be widely appreciated and understood.

Frankfurt's purpose in that essay was two-fold. First, he made a diagnosis of our times (overcoming the usual reluctancy of analytic Anglo-Saxon philosophers to making general statements about our era). He detected that we live in times in which bullshit is having a great success (although he recognized that we don't know if "there is relatively more of it nowadays than at other times. There is more communication of all kinds in our time than ever before, but the proportion that is bullshit may not have increased"10). In the second place, he gave a def-

\footnotetext{
8 H. Frankfurt, On Bullshit, “Raritan Quarterly Review” 1986, Vol. 6, No. 2, pp. 81-100.

9 H. Frankfurt, On Bullshit, Princeton 2005.

$10 \quad$ Ibid. p. 62.
} 
inition of the blunt word that he used in the title of his work. To do so, he made a sharp distinction between bullshitting and lying, along the lines that we have drawn before to distinguish between post-truth and lying. A liar is interested in truth and she wants you to believe in the general distinction between truth and falsity: she just wants you to believe as true something that is not (her lie). But, in our times, bullshitters are not interested in convincing you of one or another statement (true or false). They just want to talk with complete indifference to how things really are. And they want their audience to also be indifferent to what is true or not in their speech. The purpose of the bullshitter is not to convince her audience of new "truths"; it is just to get that audience uninterested on whether all that they are told is true or not.

The era of bullshit is then an era of general unresponsiveness to truth: a posttruth era. Although Frankfurt did not use this term, it corresponds neatly to the meaning that the journalist Steve Tesich was going to give to it in 1992, just six years after Frankfurt's original publication. Tesich was gloomily conscious of the dark consequences that this triumph of bullshit, this loss of the significance of truth, this new post-truth world, could have:

We are rapidly becoming prototypes of a people that totalitarian monsters could only drool about in their dreams. All the dictators up to now have had to work hard at suppressing the truth. We, by our actions, are saying that this is no longer necessary, that we have acquired a spiritual mechanism that can denude truth of any significance. In a very fundamental way we, as a free people, have freely decided that we want to live in some post-truth world. ${ }^{11}$

Frankfurt is not so clear as Tesich is, though, in asserting that this unresponsiveness to truth constitutes a "decision". In fact, mere carelessness is, according to him, the main cause of such an unresponsiveness. The bullshitter's fault "is not that she fails to get things right, but that she is not even trying". "I2 "It is just this lack of connection to a concern with truth-this indifference to how things really are-that I regard as of the essence of bullshit". ${ }^{13}$ Anyway, along with Tesich, Frankfurt recognized "that bullshit is a greater enemy of the truth than lies are". ${ }^{14}$ But, against Tesich again, he points out that it is precisely democracy (not a new

\footnotetext{
11 S. Tesich, A Government of Lies, “The Nation”, 1992, January 6/13, pp. 12-14.

12 H. Frankfurt, On Bullshit, Princeton 2005, p. 32.

13 Ibid. pp. 33-34.

14 Ibid. p. 61.
} 
kind of "dictatorship") what stimulates bullshitting; i.e. "the widespread conviction that it is the responsibility of a citizen in a democracy to have opinions about everything, or at least everything that pertains to the conduct of his country's affairs". ${ }^{15}$ Other instances that could explain the success of bullshit (or posttruth) in our times are, according to his book, a generalization of skepticism, in the first place (if we don't know the truth, then an indifference to it seems a good reaction). ${ }^{16}$ And, secondly, the currently prevalent praise of the virtue of sincerity ${ }^{17}$ above correctness ("let us be true to ourselves and stop trying to be true to the facts").

Frankfurt was not sympathetic neither to that skepticism nor to the corresponding aspiration to be "sincere" about ourselves: why should we get facts about ourselves better than facts in general?, he asks himself at the end of his text. In sum, he was in no way optimistic about a world in which bullshit, or post-truth, was prevailing. Interestingly, though, at the very same years in which he was dealing with these problems in Connecticut, another philosopher many miles away, in Northern Italy, was also working on them. But he was doing so from a significantly more optimistic outlook. His name was Gianni Vattimo.

\section{Gianni Vattimo: post-truth, nihilism and the media}

The pessimistic stance detectable both in Frankfurt and Tesich towards posttruth was absent from Gianni Vattimo's first edition of his book The transparent society $^{18}$ in 1989. Nevertheless, he identified a similar phenomenon in our culture to the one noticed by both Americans. A phenomenon that he did not call "posttruth" neither, but that clearly corresponded to its above explained meaning.

There were other significant differences between Frankfurt and Vattimo: instead of Wittgenstein or Saint Augustine (two of the philosophers that the American philosopher had made use of in his essay), Vattimo established a dia-

15 Ibid. pp. 63-64. This problem gets even bigger when that "citizen in a democracy" feels the compulsion to have opinions in each and every world political affair, as Frankfurt remarks immediately after; something that may help us understand the success of some of the geopolitical tactics that we will mention in section 6 of this paper.

16 Ibid. p. 64.

$17 \quad$ Ibid. p. 65.

18 G. Vattimo, La società trasparente, Milan 1989. 
logue with Nietzsche and Heidegger. Instead of being as cautious as Frankfurt on whether there is more unconcern for truth today than in the past, Vattimo plainly stated that there is: we are living in the times of accomplished nihilism, according to him (and Nietzsche), ${ }^{19}$ times characterized by this lack of concern towards absolute or factual truths. And instead of just democracy, skepticism or an exaggerated tribute to sincerity (the forces leading to post-truth that Frankfurt had identified), Vattimo emphasized another force as the main stimulus for the triumph of post-truth (and nihilism): the heroes (or the villains) of his story were the media.

His vision was somewhat prophetic. Let us remember that in 1989 the internet as we know it was still a work in progress: the first proposal for a world wide web (by Tim Berners-Lee) originated that very year, and its code was not written until the year after. Nevertheless, Vattimo was already able to envision a world very similar to today's world of the internet and social networks: a world where each person would just read the newspapers (or posts), watch the TV channels (or youtubers), listen to the radio stations (or podcasts) that hold positions similar to her own. A world, in sum, where less and less common references hold the people of one country together: there are too many media to find a shared ground for most citizens. This means that each person ends up living in a different world than their neighbor. And thus, a common notion of truth is not interesting any more: each group has its own notion of it, unresponsive to any shared criterion. Each group lives in its own post-truth environment. In fact, Vattimo was already describing what two decades afterwards would be called "cyberghettos" ${ }^{20}$ (groups of people that only consume media whose worldview coincides with their own settled worldview). Vattimo was describing our present world.

Now, as we have mentioned earlier, Vattimo's judgement of this phenomenon was initially positive. He thought that a world in which each person may freely choose their own truths was an unheard-of paradise of freedom. "If we lose the 'sense of reality' with this multiplication of world images, this loss is not a big deal

19 G. Vattimo and P. Paterlini, Non essere Dio. Un'autobiografia a quattro mani, Reggio Emilia 2006, p. 108.

20 See T.J. Johnson, S.L. Bichard \& W. Zhang, Communication Communities or 'Cyberghettos?': A Path Analysis Model Examining Factors that Explain Selective Exposure to Blogs, "Journal of Computer-Mediated Communication" 2009, Vol. 15, No. 1, pp. 60-82. In explicit connection with post-truth, Lee McIntyre has used the expression "information silos" for the same phenomenon (L. McIntyre, Post-Truth, Cambridge MA 2018). 
after all", he wrote, because it has "an emancipatory reach, a liberating reach". ${ }^{21}$ We are now free to choose our truths: is not it the height of freedom? Vattimo connects this "loss of the sense of reality" and this enjoyment of a myriad of "truths" to Nietzsche's nihilism, and nihilism also acquires in this way a positive face. Plus, using a Foucaultian concept, Vattimo added that this fragmentation of "truths" allowed the free pursuit of partial, group-limited "heterotopias", instead of the typical (and dangerous) dogmatic notions of universal utopias, oppressive models to which all of us should ideally submit. ${ }^{22}$

Anyhow, Vattimo's quite enthusiastic approval of this world of heterotopias, cyberghettos or post-truth would dramatically change just a few years afterwards. In his prologue and new last chapter ${ }^{23}$ to the reedition of this book in 2000, he recognized that maybe the media had not exercised all the "emancipatory" and "liberating" role that he had previously ascribed to them. What had happened in between to cause this change of mind? Vattimo explicitly referred to "new problems (especially political problems)". ${ }^{4}$ Political history tells us that the rise of the media tycoon Silvio Berlusconi as Italy's new prime minister, in 1994, might be behind Vattimo's new diffidence towards the media and their ability to create alternative realities. After all, post-truth had shown itself to be a good ally for right-wing populism, ${ }^{25}$ and this unexpected effect was in no way congenial to Vattimo's aspirations.

Anyway, everything that Vattimo modified then was his previous (positive) personal assessment of our post-truth times and of the role of the media in them; he still held to the philosophical idea that we were losing "a sense of reality" and entering a myriad of heterotopias, that we were entering a post-truth world. ${ }^{26}$ Let us now turn our attention to the fact that yet another Italian philosopher joined

21 G. Vattimo, La società trasparente, Milan 2000, p. 16.

22 Ibid. pp. 84-100. In spite of the relevance of Michel Foucault in bringing the notion of "heterotopia" to philosophical attention in the 1960s, Vattimo does not quote him in this text. He relies instead in philosophers like Friedrich Nietzsche and Martin Heidegger (as usual), this time in the company of Hans-Georg Gadamer and Wilhelm Dilthey. See more on the possible perils implied in universal ideals at M.Á. Quintana-Paz, L'universalismo di alcuni filosofi morali contemporanei (e le curiose idee dei drusi sui cinesi), "Filosofia e questioni pubbliche", No. 2, 2005, pp. 75-102.

23 Ibid, pp. 3-4, 101-121.

24 Ibid. p. 4.

25 We will see more on this possibility in section 6 of this paper.

26 "The philosophical background [of my position] is not undermined". Ibid. 
him (and Frankfurt) in this diagnosis: another University of Turin alumnus, whose name was Mario Perniola.

\section{Mario Perniola: post-truth and communication}

A professor of Aesthetics in Rome since 1983 and a former Situationist, Mario Perniola was at least as aware as Vattimo of the new world towards which the new media were leading us. It was already in 1986 that he was able to describe the kind of communities that the internet would create many years afterwards.$^{27}$ Nevertheless, and this is an important difference with Vattimo, he never celebrated the arrival of a world in which truth would lose relevance (a post-truth world). $\mathrm{He}$ always maintained a stern attitude to this new circumstance, evident especially in his last works. ${ }^{28}$

There are two main sources of this new situation, according to Perniola. One of them is "communication". Perniola uses this term in a quite derisive way: for him, it reflects an absolute unconcern for how things really are, substituted by a concern for talking and talking just for the sake of it. In other words, Perniola is using "communication" in a similar way to the use that Frankfurt made of "bullshit", and to the use that we are making here of "post-truth". And, like Vattimo, he contends that the media, and their communicative role, are one of the most apparent places in which this carelessness for truth may be seen.

A second important source that explains our current situation for Perniola is anti-intellectualism. He identified in the "revolution" of May 1968, and its large shadow over us, a paramount example of this anti-intellectualist movement. When students in Paris wrote on the walls things like "Read less, live more!", when they wanted to abolish universities and when some authors, like Ivan Illich, aspired to a general deschooling ${ }^{29}$ of society, they were paving the way to a world (our world) in which intellectuals, scholars, experts and knowledge in general

27 M. Perniola, "Urbano, più-che-urbano", in: Presa diretta. Estetica e politica, Venice 1986, pp. 151-160. Some years ago, I had the chance of asking Perniola how it was possible for him in the 1980s to foresee internet communities, before the invention of the world wide web. "Oh, it was all too obvious at that time" he told me with a humble look.

28 M. Perniola, Contro la comunicazione, Turin 2004; M. Perniola, Berlusconi o il '68 realizzato, Milan 2011.

29 I. Illich, Deschooling Society, New York 1971. 
would have less and less prominence. And when we throw experts out, we also throw expertise out. When we don't care about what knowledgeable experts say anymore, we confess that we don't care about the knowledge of truth anymore. A post-intellectual world is a post-truth world.

According to Perniola, this posits us in a completely new situation in Western history. In our past, even quite irrational movements, like Nazism, aspired to have some special kind of connection with truth: they had their own intellectuals, their own experts, their own cultural standards. ${ }^{30}$ "Even though hostility towards culture is not completely new in the history of Western legacy, it has never been an issue of primary importance". ${ }^{31}$ If we should want to find a similar disrespect for intellectuals and truth in the past, we would have to look East: in China experts (mandarins) had been for centuries alternating between the highest respect of their contemporaries and the deepest hatred of their fellow citizens. ${ }^{32}$ Perniola was not optimistic about a Western world that imitates today those darkest ages of Chinese history. Perniola, in sum, was not optimistic about our post-truth world.

\section{Gilles Lipovetsky: hyperindividualism, hyperconsumption and post-truth}

Now, after seeing how Frankfurt, Vattimo and Perniola made their respective diagnosis of post-truth as one of the key features of our times, let us focus on how post-truth may connect with two other prominent features of our hypermodern times: hyperindividualism and hyperconsumption. In order to do so, we will attend to one of the leading analysts of hypermodernity: the French philosopher and sociologist Gilles Lipovetsky. ${ }^{33}$

On the first place, Lipovetsky has always linked our hypermodern times with hyperindividualism. ${ }^{34}$ By this term he understands the loss of hard links among individuals, given that the traditional communities that could join them (class, religion, traditions...) are all of them declining forces in our Western world. This

\footnotetext{
M. Perniola, Berlusconi o il '68 realizzato, Milan 2011, p. 26.

Ibid. p. 25.

Ibid. pp. 26-42, 45-49.

G. Lipovetsky, Les temps hypermodernes, Paris 2004.

G. Lipovetsky, Le bonheur paradoxal: essai sur la société d'hyperconsommation, Paris 2006.
} 
lack of binding memberships has positive, "emancipatory" aspects, no doubt, but also a frightening side: individuals are now completely responsible for their own lives, for their own successes but also for their own failures. They are alone in front of the world: that is what hyperindividualism means.

Now (and here is where our analysis starts), it does not seem strange that, in such an extremely competitive context ${ }^{35}$ as today's world, this unbounded individual is prone to reject also the last bind: the bind that connects him with truth. If truth impedes my ability to compete, why not reject it? If the liberation from every bind (with class, with religion, with traditions...) is emancipatory, why not emancipate ourselves as well from truth? In fact, we have seen that Vattimo explicitly uses this language of "emancipation" and "liberation" to refer to this loss of contact with factual truths. In sum, the road from hyperindividualism to posttruth is an easy path, although it is not explicitly described with these words in Lipovetsky's work.

We can see a similar dynamic regarding a second feature of hypermodernity, according to Lipovetsky as well: hyperconsumption. If consumerism was defined as the continuous encouragement of new needs in the individual, "hyperconsumption" intensifies it by establishing an accelerated cycle of purchase, use and discard of more and more objects of consumption. "The hyperconsumer [...] wants constantly to experience new emotions through new goods". ${ }^{66}$ This accelerated speed in replacing items (so different to the old-school habit of appreciating an object more the older it gets ${ }^{37}$ ) establishes a new kind of relationship with things, with the others and with oneself ${ }^{38}$ : everything is seen as ephemeral, misoneism is substituted by ageism, duration is not a plus but a minus, mobility trumps stability.

Now, could we connect this emergence of hyperconsumption with the success of post-truth? It is clear that truth has always had characteristics quite alien

35 Lipovetsky even uses the word "Stakhanovist" to describe it (ibid., p. 251); and cites "anxiety" as one of its typical emotions (G. Lipovetsky, The Hyperconsumption Society, in: Beyond the Consumption Bubble, eds. K.M. Ekström and B. Glans, London 2011, p. 31).

36 Ibid., p. 30. An interesting fact in relation to this phenomenon is the one given by S. Kim and E. Paulos, Practices in the Creative Reuse of E-Waste, "CHI 2011", Vancouver 2011, p. 2395: 77\% of the 1.5 million Apple's iPhone 4 sales on the first day of launch in June 2010 were upgrades purchased by existing iPhone owners, who presumably were replacing a still functioning device just for the enjoyment of buying a new one.

37 S. Alba-Rico, Las reglas del caos. Apuntes para una antropología del mercado, Barcelona 1995.

38 G. Lipovetsky, Le bonheur paradoxal: essai sur la société d'hyperconsommation, Paris 2006, p. 22. 
to the ones demanded by the hyperconsumerist individual: truth intends to be stable, truth remains the same in spite of the passing of time, truth should not be discarded when it does not fit our wishes anymore. At least this are the key characteristics of truth when it is understood as correspondence to the facts. It is hardly surprising, then, that in an age of hyperconsumption, truth is substituted by post-truth. If the whims of the consumer ("the customer is always right") are supreme, then ancient and modern notions of truth as correspondence to the facts look too rigid: we need a more customable, adaptable notion of truth. And this role can be perfectly accomplished by post-truth. This is the way in which we can easily connect Lipovetsky's insistence in hyperconsumerism, as we have already done with hyperindividualism, to post-truth as a feature of hypermodern times.

In fact, there is a second trait of hyperconsumption that also fits very well with post-truth. Lipovetsky has insisted that, in hypermodernity, consumption no longer responds to traditional dynamics of distinction ${ }^{39}$ : the way we consume nowadays does not establish hard differences in taste between social classes. We do not consume this or that in order to primarily show our belonging to a distinctive social group. Rather, it is just personal satisfaction what we are looking for. ${ }^{40}$ Now, whereas truth could have a distinction role (that separates experts from amateurs, a connoisseur from an ignoramus), it is not so clear that it always carries good reasons for personal satisfaction too. This role can be much more efficiently filled by post-truth and its emotional sides. Certainly, the cost that post-truth pays for doing it is the loss of respect for experts that we have seen with Perniola: post-truth is hardly a reason for distinction between an expert and a neophyte. But in a world of hyperconsumption, as Lipovetsky insists, distinction is no longer such a highly demanded asset. Therefore, post-truth can perfectly substitute truth and all the distinctions that it carried along.

39 T. Veblen, The Theory of the Leisure Class, New York 1899; P. Bourdieu, La distinction. Critique sociale du jugement, Paris 1979. Lipovetsky calls it "phase II" of consumerism: a phase that started around 1950 and lasted till the end of the 1970s. See G. Lipovetsky, The Hyperconsumption Society, in: Beyond the Consumption Bubble, eds. K.M. Ekström and B. Glans, London 2011, p. 26.

40 "Consumption for oneself prevails over competitive or conspicuous consumption", ibid, p. 29. See also ibid, 27 and G. Lipovetsky, Le bonheur paradoxal: essai sur la société d'hyperconsommation, Paris 2006. 


\section{Post-truth as a key to understanding our times}

On the previous pages, we have seen that post-truth as a thriving trend in our times was already announced by philosophers like Harry Frankfurt, Gianni Vattimo and Mario Perniola, starting in the 1980s (although they used different names and explanations for it). We have as well seen how post-truth is congruent with two of the main traits that Gilles Lipovetsky assigns to our present: hyperindividualism and hyperconsumption. If we are correct in our analysis, then, there are philosophical reasons (alleged by Frankfurt, Vattimo and Perniola) and sociological reasons (alleged by Lipovetsky) for considering post-truth a typical feature of our hypermodern times.

Now, some may consider that such an analysis of post-truth remains on a highly speculative level (on the side of the above cited philosophers) or on a too general level (on the side of Lipovetsky as a sociologist). Is it not possible to identify more concrete events in our times which corroborate this flourishing of post-truth? Do other disciplines (apart from philosophy and sociology) verify the relevance of post-truth for understanding today's world? Although this is not the focus of this paper, we may argue that the answer to these two questions is yes. So, let us conclude by citing some of these more tangible experiences that validate post-truth a fact indispensible for understanding our hypermodern times.

Media analysis and International Relations provide us with some valuable hints of this kind. Let us focus on one of the trends of contemporary propaganda that is being more intensely studied in these academic disciplines: concretely, the kind of propaganda that the Russian Federation currently develops. Scholars have noticed that the Russian Government is deploying a quite original strategy in this sense: the main goal of its propaganda is not to convince people of some tenets anymore, as old propagandistic methods would have intended to do (tenets like: "Putin is a good ruler", or "Russian interests are more legitimate that other countries' interests", etc.). In fact, this type of ideas would be difficult to directly introduce into the minds of Western individuals. Instead, the strategic move of the Kremlin nowadays just seeks to take advantage of "Western journalistic values of presenting a plurality of views" in order to "conflate fact and fiction"41:

${ }_{41}$ A. Polyakova, M. Laruelle, S. Meister and N. Barnett, The Kremlin's Trojan Horses, Washington 2016, p. 3. See also P. Pomerantsev and M. Weiss, The Menace of Unreality: How the Kremlin Weaponizes Information, Culture, and Money, New York 2014. 
it is not essential for this tactic to persuade us of this or that doctrine, but just to generate in us distrust towards Western media or politicians. Russian disinformation does not want us to believe something, but to have a general attitude of disbelief towards our institutions and values. Maybe we will not fully assent to Sputnik or RT's ${ }^{42}$ often bizarre version of world affairs. But they can generate in us a similar skepticism towards everything that Western media might tell us about those affairs. Perhaps we will not submit to Russian authorities, but at least we will lose respect for any authoritative truths. In sum, this communication strategy that Russia promotes neatly identifies with what we have defined as "post-truth".43

Similar strategies may be seen in populist movements all around the globe, as well as in nationalistic crusades. Populism can be described as an ideology that "pits a virtuous and homogeneous people against a set of elites and dangerous 'others' who are together depicted as depriving (or attempting to deprive) the sovereign people of their rights, values, prosperity, identity, and voice". ${ }^{44}$ Now, given that (quite often) available data do not support the populist claim that "the others" are depriving us, "the virtuous", of wealth and rights, populist leaders often need to resort to disinformation, fake news and "alternative facts" 45 in order to generate a distrust of data in general. Only after cutting the ties that link the public with truth, they can make their next move and get the power. ${ }^{46}$ Post-truth becomes then an indispensable tool for their ruling goals.

42 The news agency Sputnik and the TV channel RT (formerly known as Russia Today) have been described as two of the main tools of Russian propaganda addressed to the rest of the world: B. Nimmo, Propaganda in a New Orbit, Washington 2016; J. Ioffe, What is Russia Today, "Columbia Journalism Review” 2010, September/October, https://archives.cjr.org/feature/what_is_russia_today.php?page=all.

43 On this use of propaganda not to convince us of something, but just to stabilize or destabilize authorities, see J. Stanley, How Propaganda Works, Princeton 2015. Although old media could hypothetically perform this role as well, new media (internet, social networks...) have clearly enhanced its possibilities to a previously never envisioned level; the documentary Factory of lies, by Jakob Gottschau (2018) offers a good perspective on this point.

44 D. Albertazzi and D. McDonnell, Twenty-First Century Populism, London 2008, p. 3.

45 "Alternative facts" is the famous expression used by Donald Trump's counselor Kellyanne Conway, when in January 2017 she tried to defend a false statement about the attendance numbers of the new president's inauguration. As her interviewer Chuck Todd answered to her on that occasion, "Look, alternative facts are not facts. They're falsehoods". But Conway was precisely trying to go beyond the mere dichotomy between facts and falsehoods that Todd upheld; she was trying to lay the ground for post-truth.

46 See L. McIntyre, Post-truth, Cambridge MA 2018. 
The same tactics have been identified in nationalistic forces. During the Brexit campaign, when a pro-leave supporter, the Tory politician Michael Gove, was faced with the economists' consensus that leaving the EU would be harmful for Britain, he famously stated: "I think people in this country have had enough of experts". ${ }^{47}$ It is hard to find a better summary of all the anti-intellectualism that Perniola pinpointed in post-truth. Another one of Perniola's insights, that posttruth would encourage contempt for higher education institutions, ${ }^{48}$ is recognizable in the harassment that another nationalist leader, Viktor Orbán, is deploying against the Hungarian Academy of Sciences or against one of the top universities of his country, the Central European University. ${ }^{49}$ Finally, the role of the two typical tools for post-truth, disinformation and fake news, is well known in the shaping of a third nationalist movement of our days, the one supporting the secession of Catalonia from the rest of Spain. ${ }^{50}$

\section{Concluding remarks}

As all these examples taken from our geopolitical landscape show, the flourishing of post-truth is not only an interesting position in our scholar discussions, but also a good interpretive key to understand world affairs in our hypermodern times. The bullshitting that Frankfurt keenly described, the nihilism that Vattimo first praised and then disapproved of, the careless communication that Perniola foresaw as an ever-increasing phenomenon of our times; in one word, the post-truth that academics have been analyzing for the last decades has jumped beyond their campuses and is now a key tool for politicians, propagandists and advisors. And two of the main features of our society that Lipovetsky has fa-

47 H. Mance, Britain has had enough of experts, says Gove, "Financial Times" 2016, June 6.

48 M. Perniola, Berlusconi o il '68 realizzato, Milan 2011, p. 18-22.

49 Z. Csaky, The End of Viktor Orban's Peacock Dance, "Foreign Policy" 2018, September 14 https:// foreignpolicy.com/2018/09/14/the-end-of-viktor-orbans-peacock-dance-hungary-eu-article7-epp-european-parliament

50 A. Erickson, How fake news helped shape the Catalonia independence vote, "Washington Post" 2017, October 19, https://www.washingtonpost.com/news/worldviews/wp/2017/10/19/howfake-news-helped-shape-the-catalonia-independence-vote/?utm_term=.4441b361383a; F.B. Lasheras and N. De Pedro, "Spain: the next target for Russian influence?", in: A. Polyakova et al., The Kremlin's Trojan Horses, 2, Washington 2017, pp. 20-25; R. de la Torre, Habrá que jurar que todo esto ha ocurrido, Madrid 2018. 
mously identified (hyperindividualism and hyperconsumption) are quite apt to give a further boost to this expansion of post-truth.

Should we join Frankfurt, Tesich, the later Vattimo and Perniola in the pessimistic stance that they all take towards the propagation of post-truth? Or maybe Vattimo's initial optimistic outlook is still available for us today? At this point it is assuredly useful to look back to a philosopher whose work precedes all the other authors we have dealt with insofar, but whose worries maybe were not very dissimilar. Her name was Hannah Arendt.

In fact, back in 1951, Arendt already warned us that every aspiring authoritarian can profit enormously of what we have identified as post-truth. Decades before the invention of the term, she seemed already to grasp the essence of the notion we have been talking about in this text:

The ideal subject of totalitarian rule is not the convinced Nazi or the convinced Communist, but people for whom the distinction between fact and fiction (i.e., the reality of experience) and the distinction between true and false (i.e., the standards of thought) no longer exist. ${ }^{51}$

Such and early and clear warning by Arendt about the threats involved in post-truth does not look as an inappropriate coda to this paper.

\section{Bibliography}

Alba-Rico S., Las reglas del caos. Apuntes para una antropología del mercado, Barcelona 1995.

Albertazzi D. and McDonnell D., Twenty-First Century Populism, London 2008. Arendt H., The Origins of Totalitarianism, New York 1951.

Biffi M., "Viviamo nell'epoca della post-verità?", Accademia della Crusca, 25 November 2016, http://www.accademiadellacrusca.it/it/lingua-italiana/consulenza-linguistica/domande-risposte/viviamo-nellepoca-post-verit Bourdieu P., La distinction. Critique sociale du jugement, Paris 1979.

51 H. Arendt, The Origins of Totalitarianism, New York 1951, p. 474. 
Csaky Z., The End of Viktor Orban's Peacock Dance, "Foreign Policy" 2018, September $14 \mathrm{https} / /$ foreignpolicy.com/2018/09/14/the-end-of-viktor-orbanspeacock-dance-hungary-eu-article-7-epp-european-parliament

Erickson A., How fake news helped shape the Catalonia independence vote, "Washington Post" 2017, October 19, https://www.washingtonpost.com/news/ worldviews/wp/2017/10/19/how-fake-news-helped-shape-the-catalonia-independence-vote/?utm_term $=.4441 \mathrm{~b} 361383 \mathrm{a}$

Frankfurt H., On Bullshit, "Raritan Quarterly Review" 1986, Vol. 6, No. 2, pp. 81-100.

Frankfurt H., On Bullshit, Princeton 2005.

Gottschau J., Løgnefabrikken [Factory of lies], Copenhagen 2018.

Illich I., Deschooling Society, New York 1971.

Ioffe J., What is Russia Today, "Columbia Journalism Review" 2010, September/ October, https://archives.cjr.org/feature/what_is_russia_today.php?page=all

Johnson T.J., Bichard S. L. \& Zhang W., Communication Communities or 'Cyberghettos?': A Path Analysis Model Examining Factors that Explain Selective Exposure to Blogs, "Journal of Computer-Mediated Communication" 2009, Vol. 15, No. 1, p. 60-82.

Keyes R., The Post-Truth Era. Dishonesty and Deception in Contemporary Life, New York 2004.

Kim S. and Paulos E., Practices in the Creative Reuse of E-Waste, "CHI 2011", Vancouver 2011, pp. 2395-2404.

Lasheras F.B. and De Pedro N., "Spain: the next target for Russian influence?", in: A. Polyakova et al., The Kremlin's Trojan Horses, 2, Washington 2017, pp. 20-25.

Latorre R. de la, Habrá que jurar que todo esto ha ocurrido, Madrid 2018.

Lipovetsky G., Les temps hypermodernes, Paris 2004.

Lipovetsky G., Le bonheur paradoxal: essai sur la société d'hyperconsommation, Paris 2006.

Lipovetsky G., The Hyperconsumption Society, in: Beyond the Consumption Bubble, eds. K.M. Ekström and B. Glans, London 2011, pp. 25-36.

Mance H., Britain has had enough of experts, says Gove, "Financial Times" 2016, June, 6.

McIntyre L., Post-Truth, Cambridge MA 2018.

Nimmo B., Propaganda in a New Orbit, Washington 2016. 
Perniola M., "Urbano, più-che-urbano", in: Presa diretta. Estetica e politica, Venice 1986, pp. 151-160.

Perniola M., Contro la comunicazione, Turin 2004.

Perniola M., Berlusconi o il '68 realizzato, Milan 2011.

Polyakova A., Laruelle M., Meister S. and Barnett N., The Kremlin's Trojan Horses, Washington 2016.

Pomerantsev P. and Weiss M., The Menace of Unreality: How the Kremlin Weaponizes Information, Culture, and Money, New York 2014.

Quintana-Paz M.Á., L'universalismo di alcuni filosofi morali contemporanei (e le curiose idee dei drusi sui cinesi), "Filosofia e questioni pubbliche" 2005, No. 2, pp. 75-102.

Quintana-Paz M.Á., Sapere aude, o ¿cabe llamarnos aún ilustrados?, Valladolid 2018.

Shapiro A.N., What is hyper-modernism?, Paris 2016 http://www.alan-shapiro. com/what-is-hyper-modernism-by-alan-n-shapiro

Stanley J., How Propaganda Works, Princeton 2015.

Tesich S., A Government of Lies, “The Nation” 1992, January 6/13, pp. 12-14.

Vattimo G., La società trasparente, Milan 1989.

Vattimo G., La società trasparente, Milan 2000.

Vattimo G. and Paterlini P., Non essere Dio. Un'autobiografia a quattro mani, Reggio Emilia 2006.

Veblen T., The Theory of the Leisure Class, New York 1899.

Verdú L., El prisionero de las 21.30, Barcelona 2003.

Virilio P., Vitesse et Politique: essai de dromologie, Paris 1977.

\section{Summary}

In this paper I will defend the idea of the success of post-truth as one of the main features of hypermodernity. In order to understand such a claim, I will start by defining "post-truth" and showing the key differences that separate it from simple manipulation or lies. I will explain how post-truth characterizes a whole new way of understanding the difference between truth and falsity: a new attitude of indifference to the sharp distinction that moderns and ancients had 
placed between these two notions. I will contend that this new attitude had been announced by the work of at least three recent philosophers: Harry Frankfurt, Gianni Vattimo and Mario Perniola. They give different names to "post-truth", though, and attribute it to different causes (from anti-intellectualism to the new media and to sheer carelessness). After that, I will explore how two key aspects of hypermodernity (according to Gilles Lipovetsky), i.e. hyperindividualism and hyperconsumption, cohere with this spread of post-truth. Finally, I will summarily refer to some political and geopolitical events that corroborate the relevance of post-truth in our hypermodern world.

Keywords: hypermodernity, Gianni Vattimo, Harry Frankfurt, Mario Perniola, Gilles Lipovetsky, anti-intellectualism, social networks, hyperindividualism, hyperconsumption, disinformation, populism

\section{Streszczenie}

\section{Post-prawda jako cecha hipernowoczesności}

W artykule tym będę bronił tezy, że sukces post-prawdy jest jedną z głównych cech hipernowoczesności. By twierdzenie to uczynić jak nalepiej zrozumiałym, zacznę od zdefiniowania post-prawdy i pokazania, co odróżnia ją od prostej manipulacji oraz kłamstw. Wyjaśnię, jak post-prawda odnosi się do rozumienia różnicy między prawdą i fałszem, wskazując na nowe podejście polegające na indyferencji wobec ostrego rozróżnienia, które starożytni i nowożytni wprowadzili pomiędzy tymi dwoma pojęciami. Wykażę, że podejście to zostało już zapowiedziane przez trzech współczesnych filozofów: Harry’ego Frankfurta, Gianniego Vattimo i Mario Perniolę, choć nazywali oni post-prawdę na różne sposoby i wskazywali różne jej przyczyny (od antyintelektualizmu, po nowe media i czystą beztroskę). Następnie zbadam, jak dwa kluczowe aspekty hipermodernizmu (według Gillesa Lipovetsky'ego), mianowicie hiperindywidualizm i hiperkonsumpcja, wiążą się z rozprzestrzenianiem się post-prawdy. Na koniec, pokrótce odniosę się do wydarzeń o charakterze politycznym i geopolitycznym, które potwierdzają, że post-prawda jest istotnym zjawiskiem hipernowoczesnego świata. 
Słowa kluczowe: hipernowoczesność, Gianni Vattimo, Harry Frankfurt, Mario Perniola, Gilles Lipovetsky, antyintelektualizm, sieci społecznościowe, hiperindywidualizm, hiperkonsumpcja, dezinformacja, populizm

Miguel Ángel Quintana-Paz is a professor of Ethics and Social Philosophy at the European University Miguel de Cervantes (Valladolid, Spain), where he is currently the head of the Department of Humanities. He has been a Lonergan Fellow at the Boston College and a post-doctoral researcher at the University of Turin, under the direction of Gianni Vattimo. His last books (in Spanish) are Sapere aude, or is it possible to call ourselves enlightened yet? (2018) and Rules. An Essay of Introduction to Hermeneutics with Wittgenstein and Sherlock Holmes (2017). 